\title{
Performance Evaluation of the Fe-IR-120(Na)-DEHPA Impregnated Resin in the Removal Process of As(V) from Aqueous Solution
}

Mihaela Ciopec ${ }^{1}$, Adina Negrea ${ }^{1}$, Lavinia Lupa ${ }^{1}$, Corneliu Davidescu ${ }^{1}$, Petru Negrea ${ }^{1}$ and Paula Sfârloagă

1. Faculty of Industrial Chemistry and Environmental Engineering, University "Politehnica” Timisoara, Piata Victoriei No.2, Timisoara 300006, Romania

2. National Institute for Research and Development in Electrochemistry and Condensed Matter, Timisoara, Plautius Andronescu No.1, Timisoara 300224, Romania

Received: April 09, 2011 / Accepted: April 26, 2011 / Published: September 25, 2011

\begin{abstract}
In the present paper the performance of a new functionalized material Fe-IR-120(Na)-DEHPA in the removal process of $\mathrm{As}(\mathrm{V})$ from aqueous solutions, has been investigated. The new material was obtained trough impregnation of Amberlite IR-120(Na) with di(2-ethylhexyl) phosphoric acid (DEHPA) trough the dry method. Trough impregnation of the Amberlite IR-120(Na) was obtained a resin with two functional groups which was further loaded with Fe(III) ions because of the high affinity of arsenic towards iron. The physicochemical methods of analysis (FTIR spectroscopy, EDX and SEM) approved that the impregnation with DEHPA and the iron loading, respectively, occurred. By applying the kinetic model to the experimental data it was found that the removal of As(V) ions by Fe-IR-120(Na)-DEHPA follows the pseudo-second-order rate kinetics. The linear Langmuir and Freundlich isotherm models were used to represent the experimental data and these could be well interpreted by the Langmuir isotherm. $\mathrm{R}_{\mathrm{L}}$ values between 0 and 1.0 further indicate a favorable adsorption of $\mathrm{As}(\mathrm{V})$ ions onto Fe-IR-120(Na)-DEHPA. The maximum As(V) ions uptake calculated from Langmuir model was $21.8 \mu \mathrm{g} / \mathrm{g}$.
\end{abstract}

Key words: Amberlite IR-120(Na), impregnation with DEHPA, Fe(III) ions loading, As(V) removal, kinetic studies.

\section{Introduction}

The contamination of water resources with arsenic is a serious worldwide environmental problem, due to its high toxic effect on plants, animals and humans $[1,2]$. The symptoms of chronic poisoning on human beings are numerous: skin cancer, liver, lung, kidney, and bladder cancer as well as conjunctivitis, hyperkeratosis, and in severe cases gangrene in the limbs and malignant neoplasm [3-5]. Therefore the maximum permissible limit in drinking water according to World Health Organization (WHO) is $10 \mu \mathrm{g} / \mathrm{L}$ [6-9].

Many separation techniques have been proposed for the removal of arsenic from aqueous solutions, which

Corresponding author: Mihaela Ciopec, Ph.D., scientific researcher, research field: functionalized materials in environmental protection. E-mail: mihaela.ciopec@chim.upt.ro. include oxidation-reduction, precipitation, co-precipitation, adsorption, electrolysis and cementation, solvent extraction, ion-exchange, ion flotation, biological processing and sorption [7-20]. Among these methods, adsorption and ion exchange are highly popular and have been widely practiced for toxic element removal [1-10]. Sorbents of different types like biomaterials, metal oxide/hydroxide, zeolite, activated carbon, laterite etc. have been used by workers for arsenic removal [1-10]. Organic ion exchange resins were found more suitable for the removal of toxic elements from dilute solution, due to their faster kinetics, ease of regeneration and high adsorption capacity [21-26]. While a number of studies have been reported for the removal of the toxic elements onto Amberlite XAD series impregnated with 
different extractants, none is reported about the impregnation of Amberlite IR-120(Na) [26-32]. Trough the impregnation of the IR-120(Na) it's obtained a resin with two functional groups. It was recently studied [30-38] that solutions containing $\mathrm{Cd}^{2+}$, $\mathrm{Cu}^{2+}, \mathrm{Cr}^{3+}$ ions were treated with the strong cation exchanger Amberlite IR-120 and the obtained results showed that the resin has a strong affinity for these ions, but very little is reported about arsenic removal onto Amberlite IR-120(Na).

The present study, thus, reports a detailed investigation of $\mathrm{As}(\mathrm{V})$ removal from aqueous solution using as adsorbent the strong cation exchange resin Amberlite IR-120(Na) impregnated with di(2-ethylhexyl) phosphoric acid (DEHPA) trough the dry method. Because the iron compounds in general were found to be very efficient adsorbents for arsenic removal from water due to the high affinity of arsenic towards iron [1, 6-10, 39], the obtained IR-120(Na)DEHPA resin was loaded with Fe(III) ions.

In order to determine the adsorption performance of Fe-IR-120(Na)-DEHPA resins, in the removal process of $\mathrm{As}(\mathrm{V})$ from aqueous solution, the equilibrium and kinetic studies were performed.

\section{Experiment}

\subsection{Material Preparation}

The Amberlite IR-120(Na) is a gel type strongly acidic cation exchange resin of the sulphonated polystyrene type. It was supplied by Rohm and Hass Comp. U.S.A. The resin has as functional groups the sulphonic acid. To obtain a resin with two functional groups the Amberlite IR-120(Na) was impregnated with di(2-ethylhexyl)phosphoric acid (DEHPA) trough the dry method. The DEHPA $\sim 98.5 \%$ used as extractant, was supplied by BHD Chemicals Ltd Poole England and used as received. 5 grams of dry Amberlite IR-120(Na) has been placed in $25 \mathrm{~mL}$ of ethylic alcohol containing different concentration of DEHPA $(0-0.2 \mathrm{~g} / \mathrm{mL})$ for $24 \mathrm{~h}$. The polymeric beads have been separated through a porous filter using a vacuum pump, washed with water and dried at $50{ }^{\circ} \mathrm{C}$

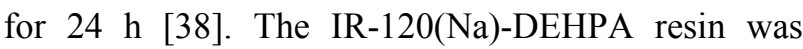
loaded with $\mathrm{Fe}(\mathrm{III})$ ions $\left(\mathrm{Fe}\left(\mathrm{NO}_{3}\right)_{3}\right.$ in $0.5 \mathrm{~mol} / \mathrm{L} \mathrm{HNO}_{3}$ solution (Merck Standard Solution), because of the high affinity of arsenic towards iron [1, 6-10, 39]. To study the influence of the DEHPA impregnation on the iron loading, $0.1 \mathrm{~g}$ of each IR-120(Na)-DEHPA obtained at different concentration of DEHPA (0-0.2 $\mathrm{g} / \mathrm{mL}$ ) was introduced in $25 \mathrm{~mL}$ of $\mathrm{Fe}$ (III) ion solutions of different concentrations $(10-200 \mathrm{mg} / \mathrm{L})$. The solutions $\mathrm{pH}$ were adjusted around the $\mathrm{pH}$ value of 3 , in order to avoid the Fe(III) ions precipitation in the solutions. The samples were kept in contact for $24 \mathrm{~h}$, and after that were filtrated and the residual concentration of the iron ions was determined trough atomic adsorption spectrophotometry using a Varian SpectrAA 280FS Spectrophotometer. The dependence of the $\mathrm{Fe}$ (III) ions uptake versus the initial concentration of $\mathrm{Fe}$ (III) ions from solution for each IR-120(Na)-DEHPA obtained at different concentration of DEHPA and also the dependence of the Fe(III) ions uptake versus the concentration of the DEHPA used for impregnation, was established. The sample of IR-120(Na) and the samples of Fe-IR-120(Na)-DEHPA respectively, were submitted to physicochemical methods of analysis (FTIR spectroscopy, EDX and SEM) in order to establish if the impregnation with DEHPA and the iron loading occurred. The FTIR spectra were recorded using a Shimadzu FTIR spectrophotometer in the range $4,000-400 \mathrm{~cm}^{-1}$ with $2 \mathrm{~cm}^{-1}$ resolution and 40 scans using $\mathrm{KBr}$ discs. SEM micrographs and EDX studies were performed using a FEI Inspect $\mathrm{S}$ scanning electron microscope.

\subsection{Arsenic Removal}

The influence of the contact time and initial concentration of arsenic upon the arsenic removal process from aqueous solution was investigated.

In the first instance the effect of contact time was studied for all the obtained materials. In order to 
establish the arsenic removal performance the experiments were performed with $0.1 \mathrm{~g}$ of each obtained material in $0.025 \mathrm{~L}$ of $100 \mu \mathrm{g} / \mathrm{L} \mathrm{As}(\mathrm{V})$ solution. The samples were kept in contact for different times (range: 1-24 h) at the room temperature $25 \pm$ $1{ }^{\circ} \mathrm{C}$. After contact time elapsed, the suspensions were filtered and the residual concentration of $\mathrm{As}(\mathrm{V})$ ions in the filtrates was determined by means of atomic absorption spectrometry using a Varian SpectrAA 110 atomic absorption spectrometer with a Varian VGA 77 hydride generation system. To determine the best materials used in the removal process of $\mathrm{As}(\mathrm{V})$ from aqueous solution the dependence of the $\operatorname{As}(\mathrm{V})$ uptake versus the contact time for each studied materials was illustrated. In order to express the kinetics of arsenic removal onto Fe-IR-120(Na)-DEHPA and to find out the mechanism of arsenic removal the results were analyzed using the following models:

The pseudo-first-order kinetic model proposed by Lagergren, based on the solid adsorption capacity can be used to determine the rate constant for the removal process and the integrated form is expressed by the Eq. (1) $[3,7,12,23,25,26,30,38,39]$ :

$$
\ln \left(\mathrm{q}_{e}-\mathrm{q}_{t}\right)=\ln \mathrm{q}_{e}-\mathrm{k}_{1} \mathrm{t}
$$

where: $q_{t}$ and $q_{e}$ represent the amounts of the arsenic uptake onto the studied material at time " $t$ " and at equilibrium time, respectively, $\mu \mathrm{g} / \mathrm{g} ; k_{1}$ is the specific adsorption rate constant $\left(\mathrm{min}^{-1}\right)$.

The linear form of the pseudo-second-order rate expression of Ho and Mckay, based on the solid phase sorption, is given by Refs [3, 7, 12, 23, 25, 26, 30, 38, 39]:

$$
\frac{\mathrm{t}}{\mathrm{q}_{t}}=\frac{1}{\mathrm{~h}}+\frac{\mathrm{t}}{\mathrm{q}_{e}}
$$

where: $\mathrm{h}=\mathrm{k}_{2} \cdot \mathrm{qe}_{\mathrm{e}}^{2} ; \mathrm{k}_{2}$ is the pseudo-second-order constant, $\min ^{-1}(\mu \mathrm{g} / \mathrm{g})^{-1}$.

To study the effect of the initial concentration of $\mathrm{As}(\mathrm{V})$, in each experiments $0.1 \mathrm{~g}$ of studied material was suspended in $25 \mathrm{~mL}$ of $\mathrm{As}(\mathrm{V})$ solution of different concentration (range: $10-400 \mu \mathrm{g} / \mathrm{L}$ ) for $16 \mathrm{~h}$ at the room temperature. After contact time elapsed the filtrate was collected for $\mathrm{As}(\mathrm{V})$ analysis.

In order to determine the $\mathrm{As}(\mathrm{V})$ maximum uptake of the studied material two important isotherm models were chosen to fit the experimental data in this study: Langmuir and Freundlich [3-5, 7, 23, 25, 26, 30, 38, 39].

The linear form of the Langmuir equation is expressed by:

$$
\frac{\mathrm{C}_{\mathrm{e}}}{\mathrm{q}_{\mathrm{e}}}=\frac{1}{\mathrm{~K}_{\mathrm{L}} \mathrm{q}_{\mathrm{m}}}+\frac{\mathrm{C}_{\mathrm{e}}}{\mathrm{q}_{\mathrm{m}}}
$$

The linear form of the Freundlich isotherm equation can be written as:

$$
\ln \mathrm{q}_{e}=\ln \mathrm{K}_{F}+\frac{1}{\mathrm{n}} \ln C_{e}
$$

where: $q_{e}$ is the amount of arsenic uptake per gram of sorbent $(\mu \mathrm{g} / \mathrm{g}) ; C_{e}$ is the equilibrium concentration of arsenic $(\mu \mathrm{g} / \mathrm{L}) ; K_{f}$ and $1 / \mathrm{n}$ are characteristic constants that can be related to the relative adsorption capacity of the adsorbent and the intensity of adsorption, respectively; $q_{m}$ is a measure of monolayer adsorption capacity $(\mu \mathrm{g} / \mathrm{g})$ and $K_{L}$ is a constant related to the free energy of adsorption.

The various chemicals employed in the experiments were of A.R. grade and used without further purification. Distilled water was used throughout.

The solutions of $\mathrm{As}(\mathrm{V})$ were prepared by appropriate dilution from a stock solution which was prepared by diluting an appropriate amount of $\mathrm{H}_{3} \mathrm{AsO}_{4}$ in $0.5 \mathrm{M}$ $\mathrm{HNO}_{3}$ solution (Merck Standard Solutions).

All the experiments for arsenic removal process were performed at a initial $\mathrm{pH}$ of $\mathrm{As}(\mathrm{V})$ solution of 9, because the predominant anionic species of $\mathrm{As}(\mathrm{V})$ $\left[\mathrm{H}_{2} \mathrm{AsO}_{4}{ }^{-}\right.$or $\left.\mathrm{HAsO}_{4}{ }^{2-}\right]$ are found in the environment samples at this $\mathrm{pH}$ value $[3,7,8]$.

The Fe(III) and $\mathrm{As}(\mathrm{V})$ uptake, respectively, $q_{e}(\mathrm{mg} / \mathrm{g}$ and $\mu \mathrm{g} / \mathrm{g}$, respectively), is determined according to the next corresponding mass balance expression $[3-5,7,12$, $23,25,26,30,38,39]$ :

$$
\mathrm{q}_{e}=\left(\mathrm{C}_{0}-\mathrm{C}_{e}\right) \frac{\mathrm{v}}{\mathrm{m}}
$$

where: $\mathrm{C}_{0}$ and $\mathrm{C}_{\mathrm{t}}$ are the concentrations of $\mathrm{Fe}(\mathrm{III})$ and $\mathrm{As}(\mathrm{V})$ ions, respectively, $(\mathrm{mg} / \mathrm{L}$ and $\mu \mathrm{g} / \mathrm{L}$, respectively) 
in the solution initially $(t=0)$ and after a time $\mathrm{t}(\mathrm{min})$, respectively, $V$ is the volume of the solution (L) and $m$ is the mass of material employed (g).

\section{Results and Discussion}

\subsection{Evaluation of the Material Preparation Process}

The experimental data regarding the dependence of the $\mathrm{Fe}$ (III) ions uptake versus the initial concentration of $\mathrm{Fe}$ (III) ions from solution, for each IR-120(Na)-DEHPA, obtained at different concentration of DEHPA, are presented in Fig. 1.

The experimental data show the increase of the $\mathrm{Fe}(\mathrm{III})$ ions uptake as the initial concentration of $\mathrm{Fe}$ (III) ions from solution increases, for each studied material. After an initial concentration of $\mathrm{Fe}(\mathrm{III})$ ions of $100 \mathrm{mg} / \mathrm{L}$ the increasing of the $\mathrm{Fe}(\mathrm{III})$ ions is not so significant. In conclusion the optimum concentration of the $\mathrm{Fe}(\mathrm{III})$ ions in the process of the iron loading onto IR-120(Na)-DEHPA is $100 \mathrm{mg} / \mathrm{L}$ for a $\mathrm{S}: \mathrm{L}$ ratio of 0.1:0.025.

The experimental data regarding the dependence of the $\mathrm{Fe}(\mathrm{III})$ ions uptake versus the concentration of the DEHPA used for impregnation in case of an initial concentration of $\mathrm{Fe}(\mathrm{III})$ ions of $100 \mathrm{mg} / \mathrm{L}$ are presented in Fig. 2.

It can be noticed that the $\mathrm{Fe}$ (III) ions uptake increase with the increasing of the DEHPA concentration, used in the impregnation process of the IR-120(Na). The results allow us to suppose that the Fe(III) ion loading is realised: on one hand, because of the cation exchange process between the $\mathrm{Na}$ ions from the studied resin and $\mathrm{Fe}(\mathrm{III})$ ions from the aqueous solution and on the other hand, because of the Fe(III) ions loading onto the second functional group from the studied resin resulted after the impregnation of the Amberlite IR-120(Na) with DEHPA.

If our supposition is true, these results also demonstrate that with the increasing of the DEHPA concentration, used for impregnation of the studied material, increase the acid quantity sorbed by the resin, which is expected to be confirm by the EDX analysis.

Fig. 3 displays the FTIR spectra of the Amberlite IR-120(Na) and of the material obtained after resin impregnation with DEHPA $\left(\mathrm{C}_{\mathrm{i}}=0.2 \mathrm{~g}\right.$ DEHPA $/ \mathrm{mL}$ solvent) and Fe(III) loading $\left(\mathrm{C}_{\mathrm{i}}=100 \mathrm{mg} / \mathrm{L}\right)$.

From the IR spectrum of the both sample we observe

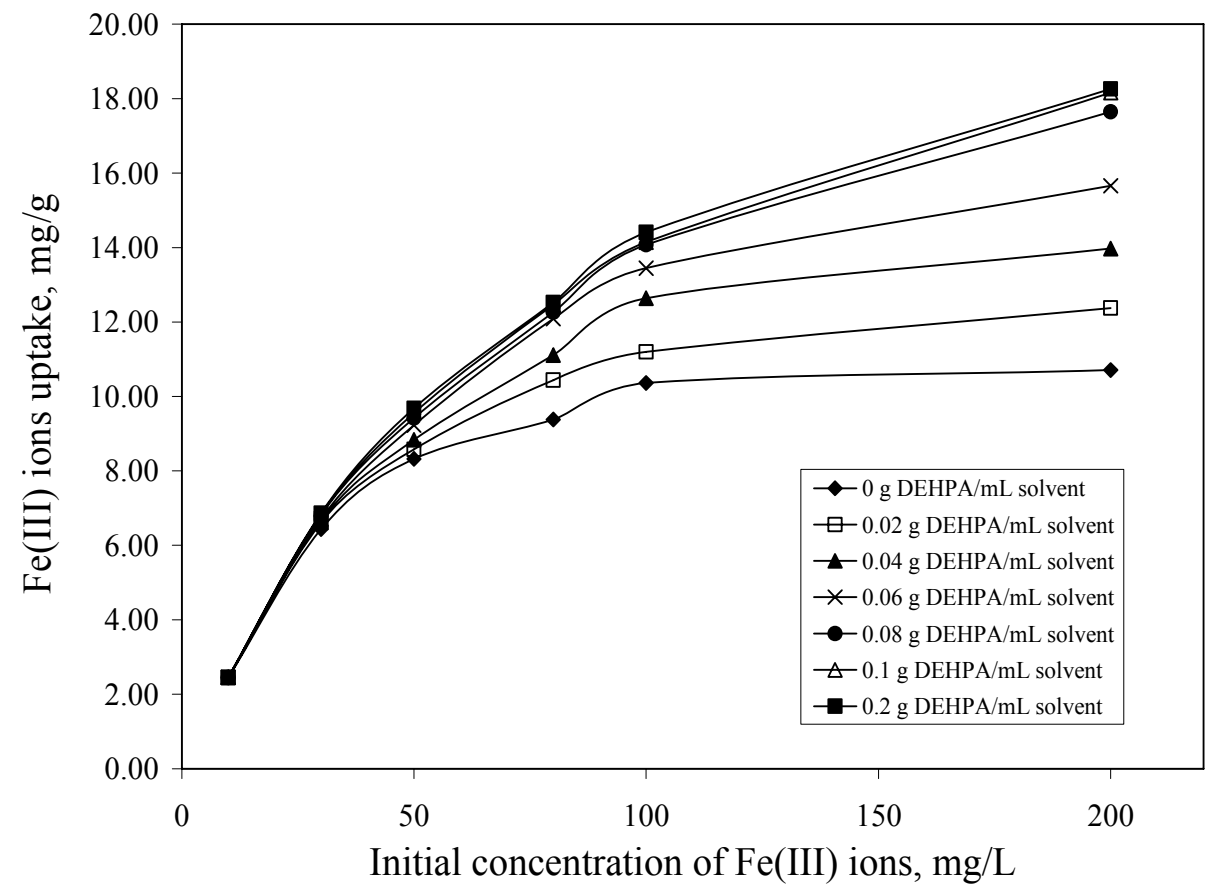

Fig. 1 Dependence of the Fe(III) ions uptake versus the initial concentration of Fe(III) ions from solution for each IR-120(Na)-DEHPA (pH = 3, t = 24 h, $\mathrm{m}=0.1 \mathrm{~g}, \mathrm{v}=0.025 \mathrm{~L})$. 


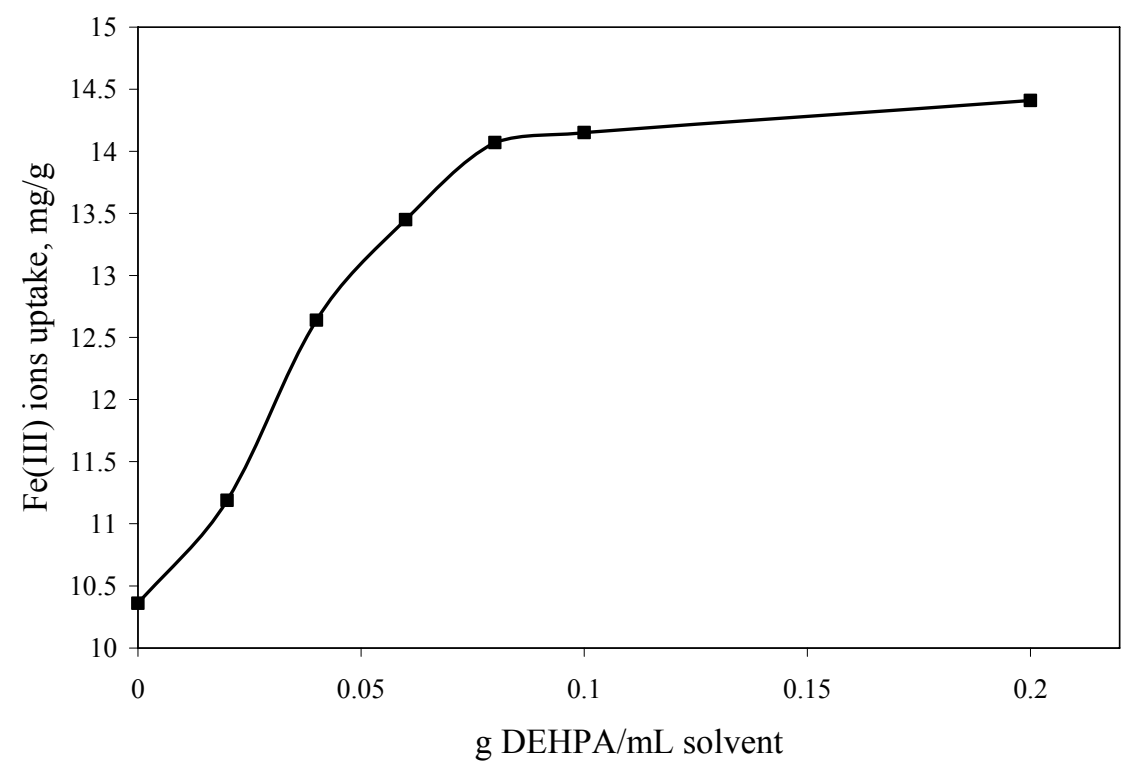

Fig. 2 Dependence of the Fe(III) ions uptake versus the concentration of the DEHPA used for impregnation (pH=3, $t=24 \mathrm{~h}, \mathrm{~T}$ $=25 \pm 1^{\circ} \mathrm{C}, \mathrm{m}=0.1 \mathrm{~g}, \mathrm{v}=0.025 \mathrm{~L}, \mathrm{C}_{\mathrm{iFe}}=100 \mathrm{mg} / \mathrm{L}$ ).

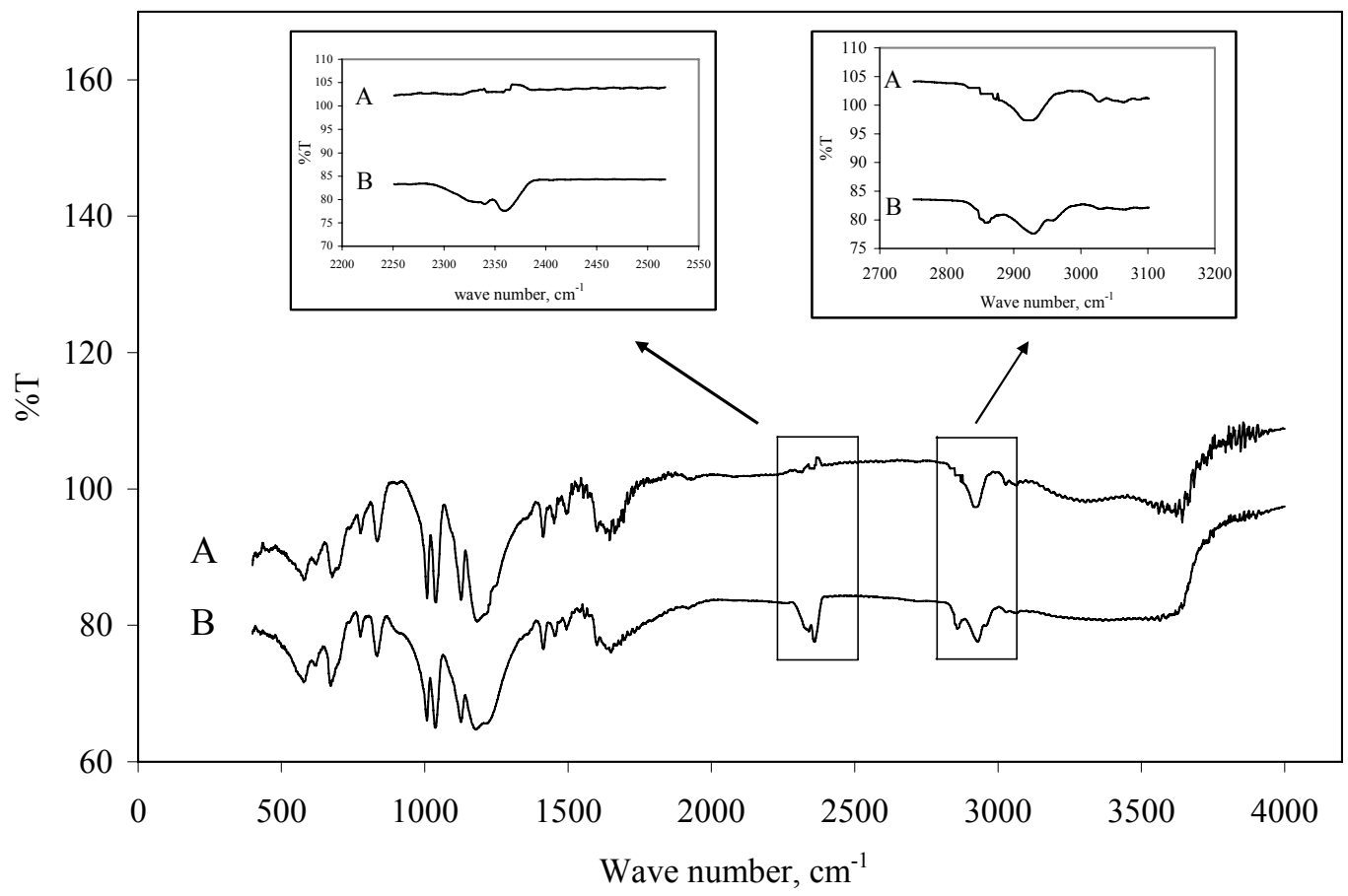

Fig. 3 IR spectra of IR-120(Na)-sample A and Fe-IR-120(Na)-DEHPA-sample B.

the common bands of the Amberlite IR-120(Na): 2,975 $\mathrm{cm}^{-1}$-C-H stretching of $\mathrm{CH}_{3} ; 2,890 \mathrm{~cm}^{-1}$-aliphatic C-H stretching; $1,650 \mathrm{~cm}^{-1} \mathrm{C}=\mathrm{C} ; 1,000-1,030-\mathrm{S}-\mathrm{O} ; 600-700$ $\mathrm{cm}^{-1} \mathrm{C}-\mathrm{S}$. Besides these common bands the spectrum of Fe-IR-120(Na)-DEHPA exhibits a clear band at 2,340 $\mathrm{cm}^{-1}$ specific for P-OH stretching; and at 2,890 $\mathrm{cm}^{-1}$ for Fe-OH. Also can be seen a small band at 1,230 $\mathrm{cm}^{-1}$ for $\mathrm{P}=\mathrm{O}$ stretching. The other specific bands for Fe-OH (at 1,037 $\mathrm{cm}^{-1}$ ) and for P-O-C stretching (at $1,029 \mathrm{~cm}^{-1}$ ) can not be clear identified because of their interaction between them and the specific band for the -S-O stretching (1,000-1,030 $\left.\mathrm{cm}^{-1}\right)$. This proves the adsorption of DEHPA and the loading of Fe(III) ions, respectively, onto the Amberlite IR-120(Na) resin. 
A scanning electron micrograph of the IR-120(Na) and Fe-IR-120(Na)-DEHPA are presented in Fig. 4.

The Amberlite IR-120(Na) (Fig. 4a) consisted of spherical granules which have a smooth surface under the highly magnified SEM images $(3000 \times)$. In case of Fe-IR-120(Na)-DEHPA $\left(\mathrm{C}_{\text {iDEHPA }}=0.02 \mathrm{~g} / \mathrm{mL}\right.$ solvent;
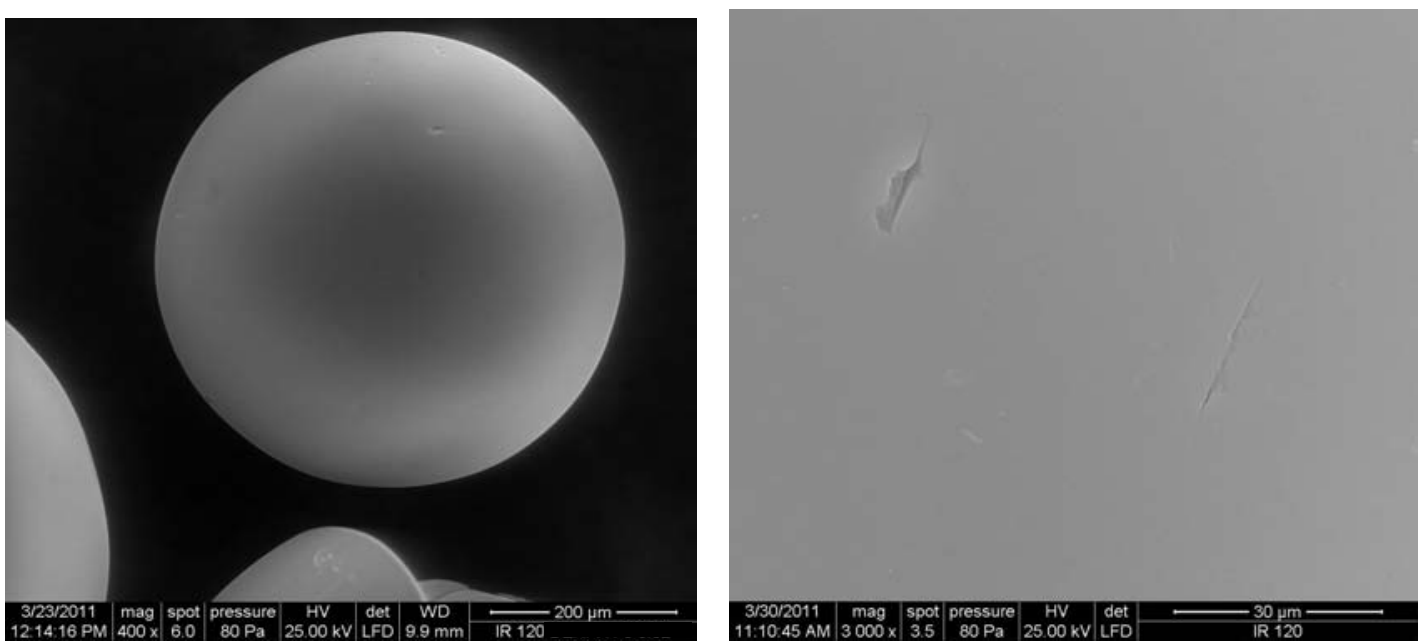

(a)
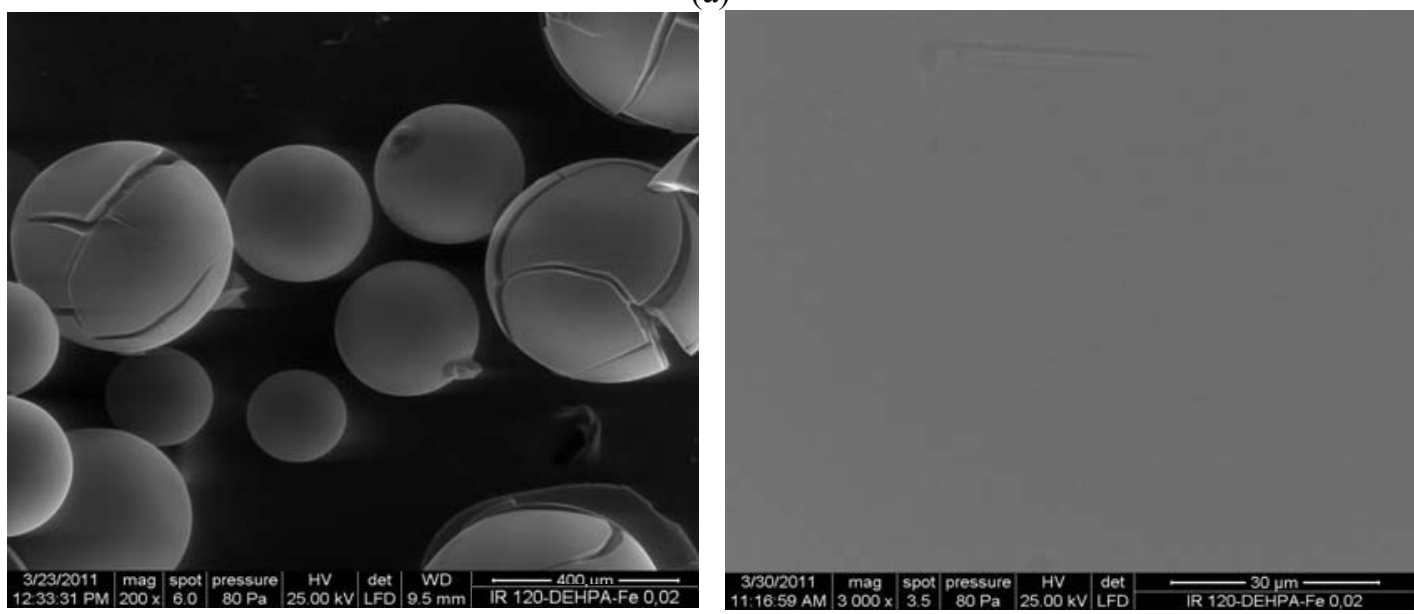

(b)
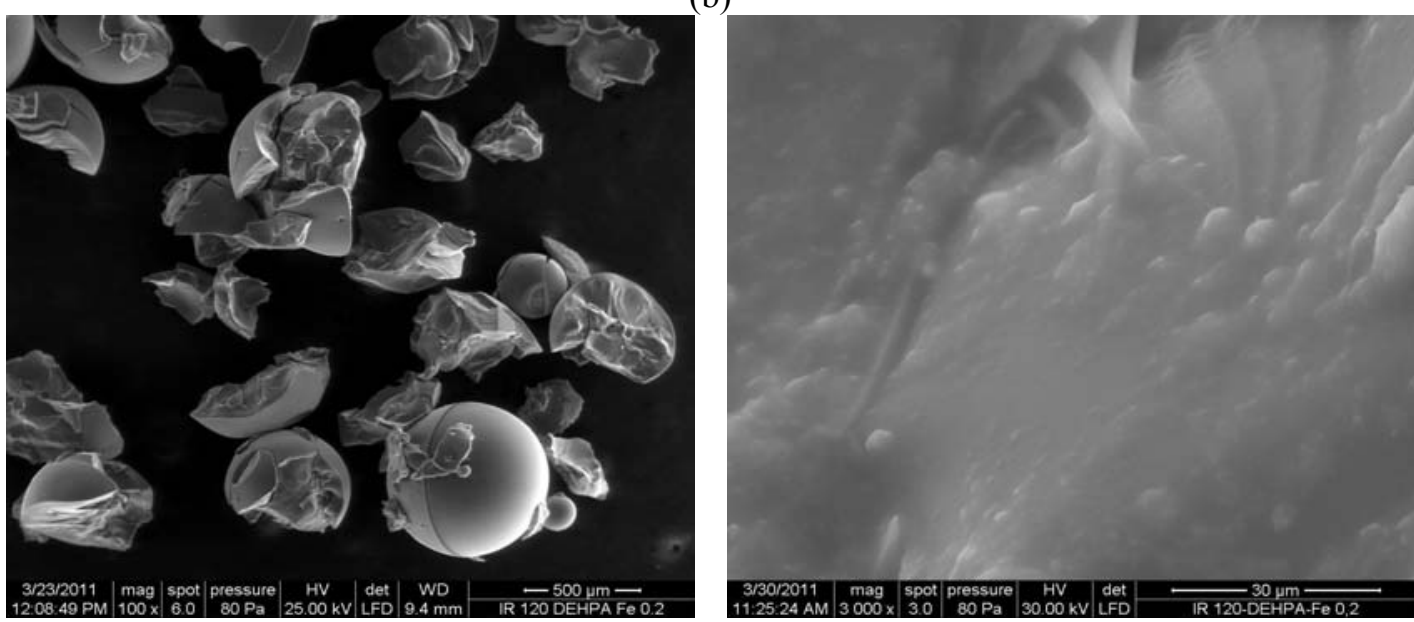

(c)

Fig. 4 Scanning electron micrograph of (a) IR-120(Na); (b) Fe-IR-120(Na)-DEHPA $\left(C_{i D E H P A}=0.02 \mathrm{~g} / \mathrm{mL}\right.$ solvent; $\mathrm{C}_{\mathrm{iFe}}=100$ $\mathrm{mg} / \mathrm{L}$ ); (c) Fe-IR-120(Na)-DEHPA ( $C_{\text {iDEHPA }}=0.2 \mathrm{~g} / \mathrm{mL}$ solvent; $\left.C_{i F e}=100 \mathrm{mg} / \mathrm{L}\right)$. 
$\mathrm{C}_{\mathrm{iFe}}=100 \mathrm{mg} / \mathrm{L}$ ) the spherical granules have small fissures, but the surface is still smooth (Fig. 4b). The increasing of the DEHPA initial concentration in the impregnation process of the Amberlite IR-120(Na) resin leads to granules smashes, and the surface consisted of conglomerates with open porosity (Fig. $4 c)$, which is expected to develop a higher adsorption capacity of $\mathrm{As}(\mathrm{V})$.

The EDX spectrums of the studied materials are presented in Fig. 5. One may notice the presence of the characteristic peak of phosphorous and iron ions. This also proves the adsorption of DEHPA and the loading of $\mathrm{Fe}$ (III) ions on the IR-120(Na) support. Also, it can be observed that, both the characteristic peak of phosphorous, and also, of the iron ions, increase with the DEHPA concentration increases in the impregnation process of the resin. These results demonstrate that with the increasing of the DEHPA concentration, used for impregnation of the studied material, increase the acid quantity sorbed by the resin and consequently increase the quantity of iron ions loaded onto the studied materials.

\subsection{Evaluation of the Arsenic Removal Performance of the Studied Material}

\subsubsection{Effect of Contact Time}

The experimental data regarding the dependence of the $\mathrm{As}(\mathrm{V})$ uptake versus contact time for all the studied materials, obtained at different concentration of DEHPA, used in the impregnation process, and at an initial concentration of Fe(III) ions of $100 \mathrm{mg} / \mathrm{L}$, used in the iron loading process, are presented in Fig. 6.

It can be observed that the equilibrium time is achieved in $16 \mathrm{~h}$ for all the studied materials. For subsequent experiments, an equilibrium time of $16 \mathrm{~h}$ was chosen for the sake of convenience. One may notice that the $\operatorname{As}(\mathrm{V})$ uptake increase with the increasing of the DEHPA concentration used in the impregnation process of the resin. This effect is not so significant for a concentration of DEHPA higher than $0.08 \mathrm{~g} / \mathrm{mL}$ of solvent. From this reason the optimum concentration of the DEHPA used in the impregnation process is that of $0.08 \mathrm{~g} / \mathrm{mL}$ of solvent. These results confirm the expectation concerning the $\mathrm{As}(\mathrm{V})$ removal performance of the sample after morphology of surface area analysis.

To elucidate the removal mechanism different rate law were tested to unfold the best fitting kinetic model to the experimental results in case of use as adsorbent material the Fe-IR-120(Na)-DEHPA obtained in case of an initial concentration of DEHPA of $0.08 \mathrm{~g} / \mathrm{mL}$ of solvent used in the impregnation process and at an initial concentration of $\mathrm{Fe}(\mathrm{III})$ of $100 \mathrm{mg} / \mathrm{L}$. The pseudo-first-order rate constant may be determined from the linear plot of $\ln \left(q_{e}-q_{t}\right)$ versus $t$ (Fig. 7), while the pseudo-second-order rate constant can be estimated from the linear plot of $t / q_{t}$ versus $t$ (Fig. 8). The values of these constants determined as indicated, together with the corresponding regression coefficients $\left(\mathrm{R}^{2}\right)$, are listed in Table 1.

Data presented in Table 1 show that the correlation coefficient for the pseudo-first-order kinetic model is lower than that obtained for the pseudo-second-order model, where the correlation coefficient is very close to 1. Furthermore, the value of the equilibrium sorption capacity calculated $\left(\mathrm{q}_{\mathrm{e}, \mathrm{kinetic}}\right.$ plot $)$ using the first-order model, is not close to the experimental value $\left(\mathrm{q}_{\mathrm{e}, \text { exp }}\right)$. In the case of the pseudo-second-order model the theoretically predicted equilibrium sorption capacity is close to the value experimentally determined. This shows that the kinetics of $\mathrm{As}(\mathrm{V})$ removal by sorption on the Fe-IR-120(Na)-DEHPA is described by a pseudo-second-order expression.

\subsubsection{Effect of $\mathrm{As}(\mathrm{V})$ Initial Concentration}

To determine the maximum $\mathrm{As}(\mathrm{V})$ uptake by the Fe-IR-120(Na)-DEHPA experimentally obtained, the dependence of the $\mathrm{As}(\mathrm{V})$ uptake versus the equilibrium concentration is presented in Fig. 9. The maximum $\operatorname{As}(\mathrm{V})$ uptake experimentally determined is $18.6 \mu \mathrm{g} / \mathrm{g}$.

The equilibrium data have been correlated with the Freundlich and Langmuir isotherms. The curves and 


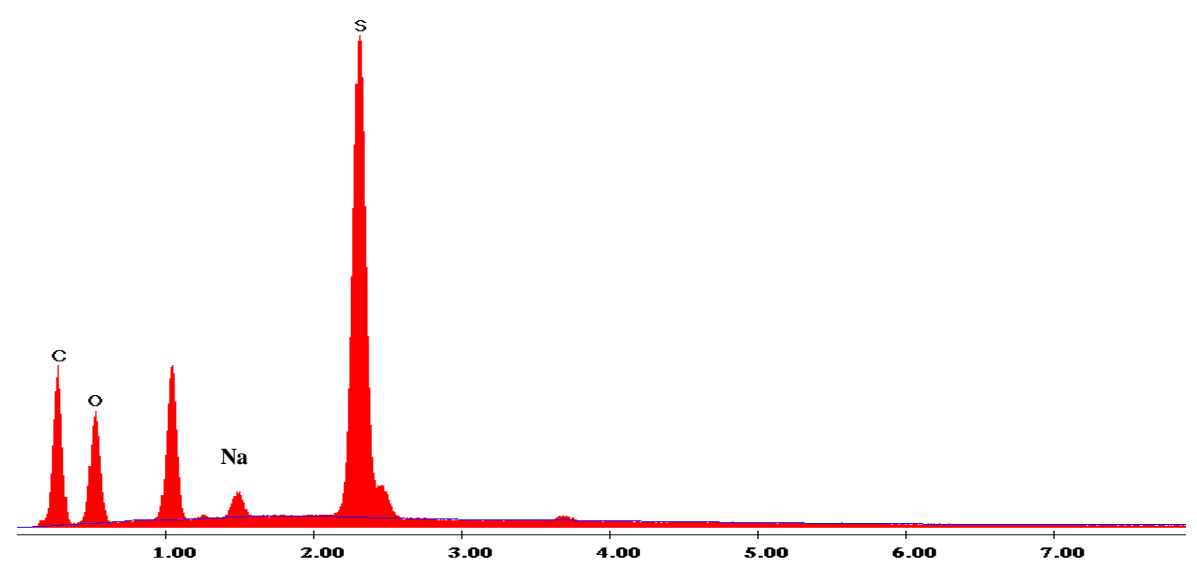

(a)

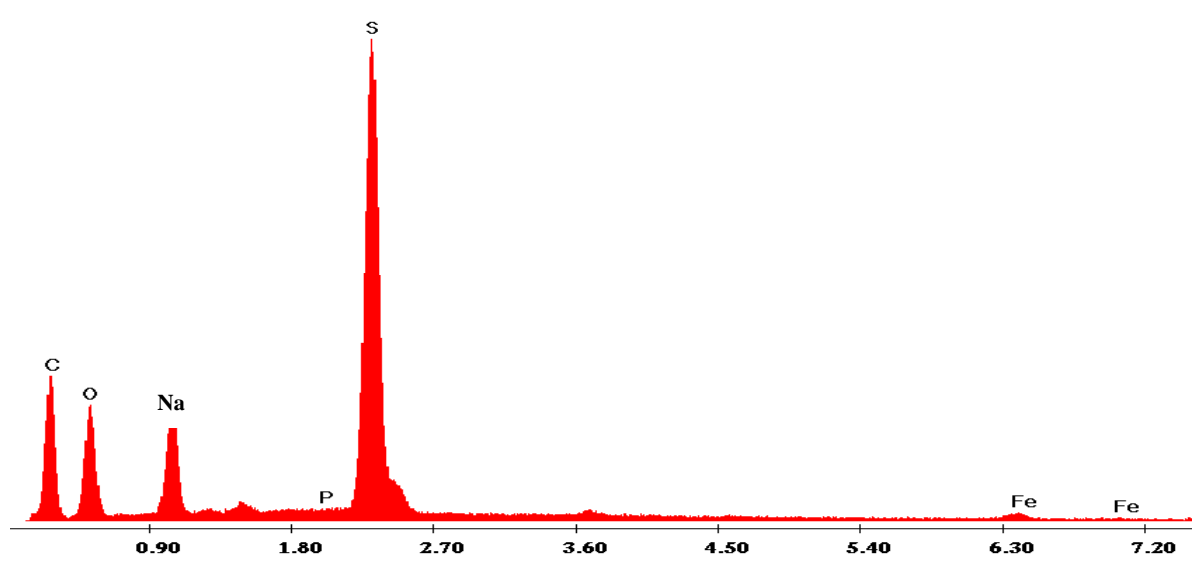

(b)

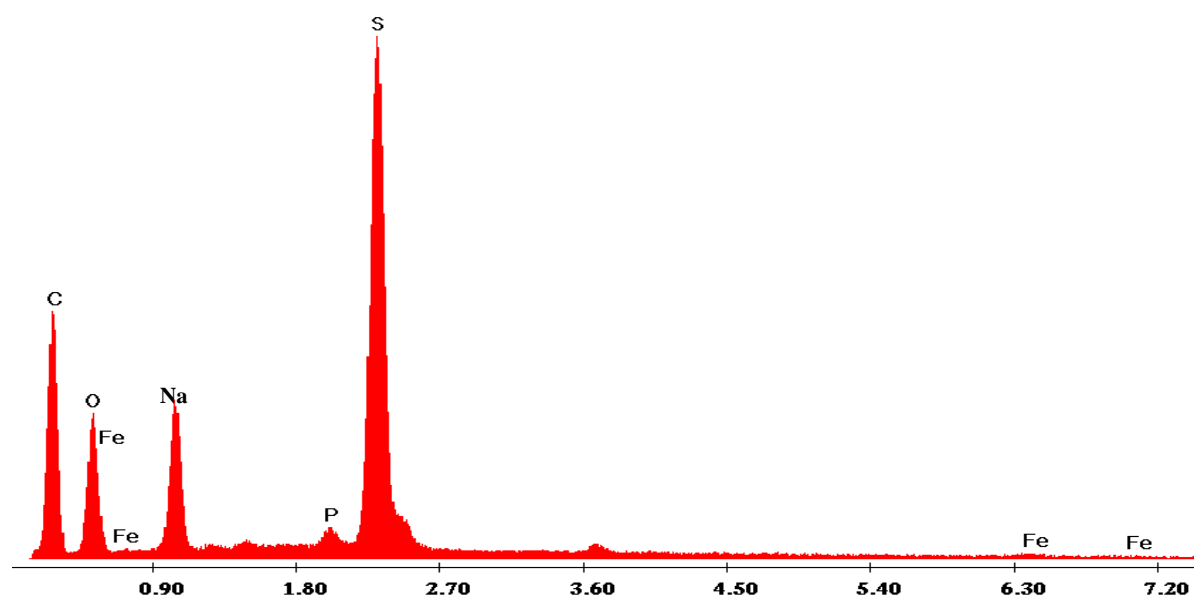

(c)

Fig. 5 EDX spectrum of (a) IR-120(Na); (b) Fe-IR-120(Na)-DEHPA (C $\mathrm{C}_{\mathrm{iDEHPA}}=0.02 \mathrm{~g} / \mathrm{mL}$ solvent; $\left.\mathrm{C}_{\mathrm{iFe}}=100 \mathrm{mg} / \mathrm{L}\right)$; (c) Fe-IR-120(Na)-DEHPA $\left(C_{\text {iDEHPA }}=0.2 \mathrm{~g} / \mathrm{mL}\right.$ solvent; $\left.C_{i F e}=100 \mathrm{mg} / \mathrm{L}\right)$. 

of $\mathrm{As}(\mathrm{V})$ from Aqueous Solution

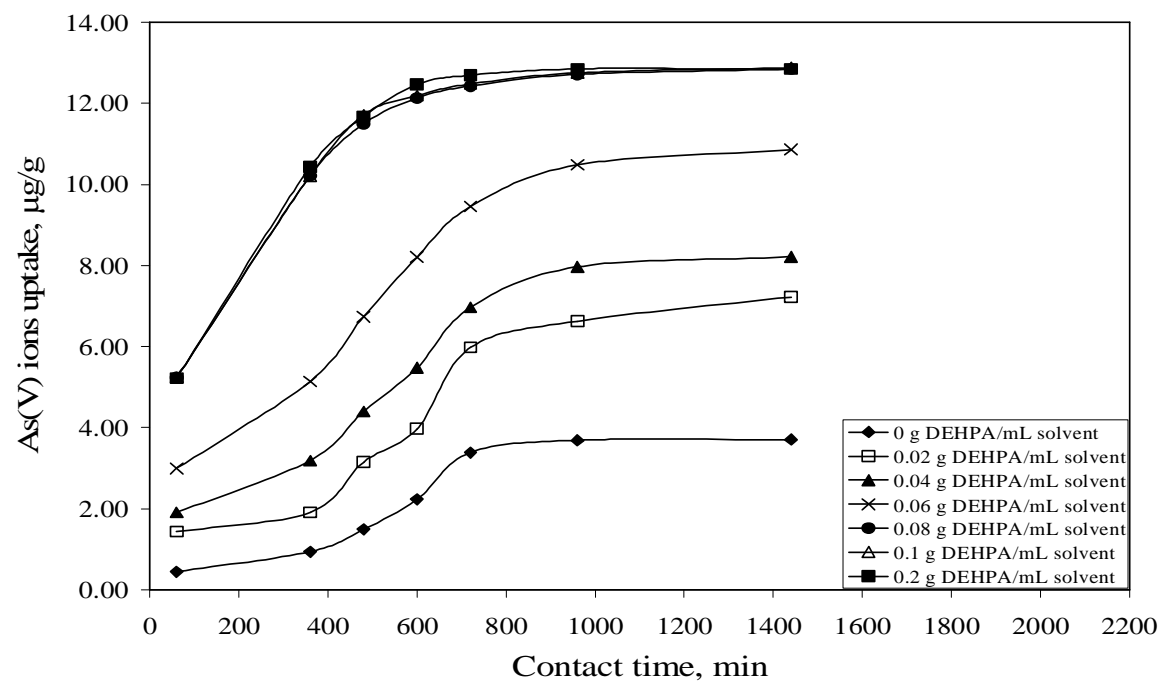

Fig. 6 Effect of contact time on $\operatorname{As}(\mathrm{V})$ uptake $\left(\mathrm{pH}=9, \mathrm{~T}=25 \pm 1^{\circ} \mathrm{C}, \mathrm{C}_{\mathrm{iAs}}=100 \mu \mathrm{g} / \mathrm{L}, \mathrm{m}=0.1 \mathrm{~g}, \mathrm{v}=0.025 \mathrm{~L}\right)$.

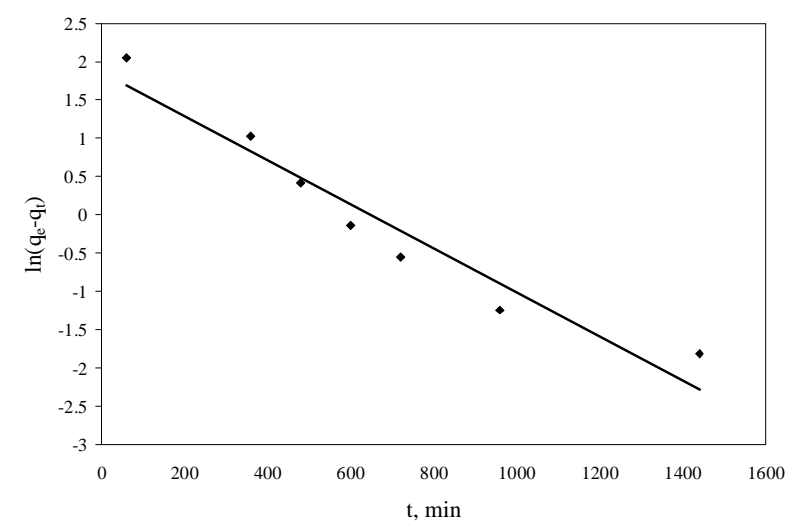

Fig. 7 Pseudo-first-order kinetic plot for $\operatorname{As}(\mathrm{V})$ removal process.

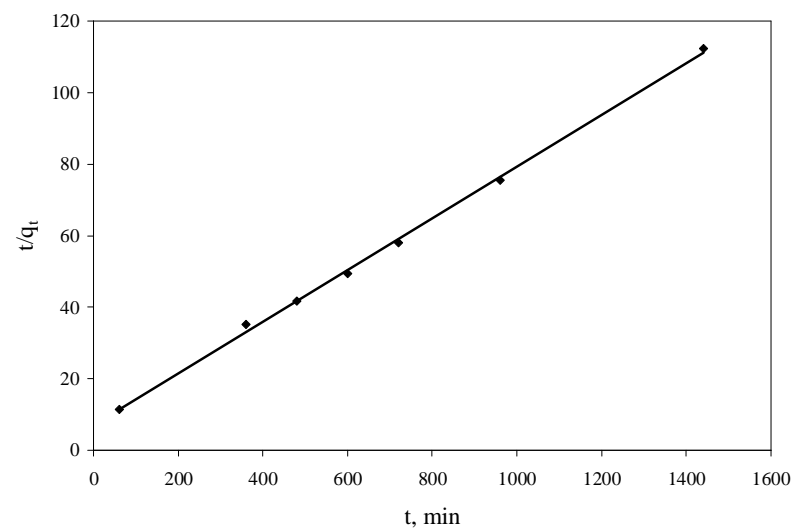

Fig. 8 Pseudo-second-order kinetic plot for $\operatorname{As}(\mathrm{V})$ removal process.

Table 1 Kinetic model parameters for As(V) ions removal by Fe-IR-120(Na)-DEHPA.

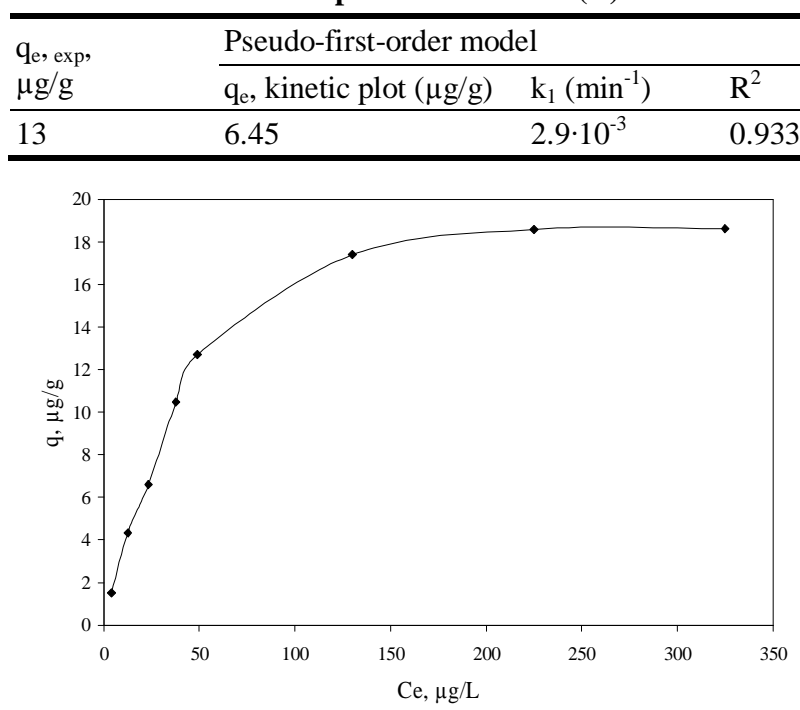

Fig. 9 The dependence of the $\operatorname{As}(\mathrm{V})$ metal uptake versus the equilibrium concentration $(\mathrm{pH}=9, \mathrm{t}=16 \mathrm{~h}, \mathrm{~T}=25 \pm$ $1^{\circ} \mathrm{C}, \mathrm{m}=0.1 \mathrm{~g}, \mathrm{v}=0.025 \mathrm{~L}$ ).
Pseudo-second-order model

$\mathrm{q}_{\mathrm{e}}$, kinetic plot $(\mu \mathrm{g} / \mathrm{g}) \quad \mathrm{k}_{2}\left[\mathrm{~min}^{-1}(\mu \mathrm{g} / \mathrm{g})^{-1}\right]$

13.8
$7.21 \cdot 10^{-4}$

0.9986

parameters, as well as the correlation coefficients $\left(\mathrm{R}^{2}\right)$ for $\mathrm{As}(\mathrm{V})$ removal by Fe-IR-120(Na)-DEHPA are presented in Figs. 10 and 11 and Table 2.

The Freundlich plot has a correlation coefficient very low; this suggests a restriction on the use of Freundlich isotherms. The numerical value of $1 / \mathrm{n}<1$, which provides information about surface heterogeneity and surface affinity for the solute, indicates a favorable sorption of $\mathrm{As}(\mathrm{V})$ and a very high affinity of the Fe-IR-120(Na)-DEHPA for As(V).

The Langmuir model effectively describes the sorption data with a correlation coefficient of 0.9938 . 


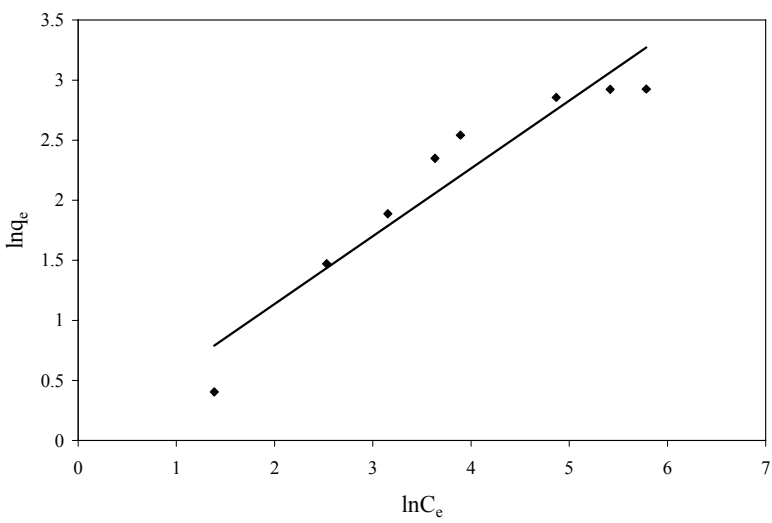

Fig. 10 Freundlich plot of $\operatorname{As}(\mathrm{V})$ adsorption on Fe-IR-120(Na)-DEHPA.

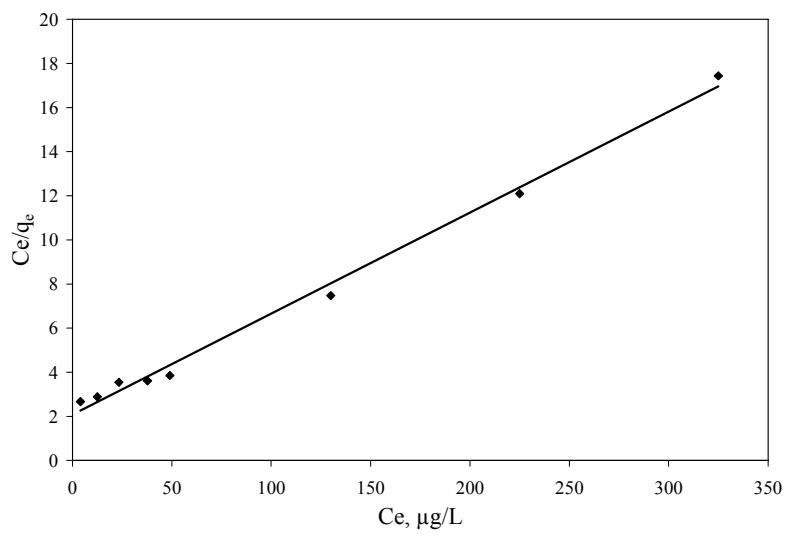

Fig. 11 Langmuir plot of $\mathrm{As}(\mathrm{V})$ adsorption on Fe-IR-120(Na)-DEHPA.

Table 2 Parameters of different isotherm for the As(V) adsorption on Fe-IR-120(Na)-DEHPA.

\begin{tabular}{|c|c|c|c|c|c|}
\hline \multicolumn{3}{|c|}{ Freundlich isotherm } & \multicolumn{3}{|c|}{ Langmuir isotherm } \\
\hline $\mathrm{K}_{\mathrm{F}}(\mu \mathrm{g} / \mathrm{g})$ & $1 / \mathrm{n}$ & $\mathrm{R}^{2}$ & $\mathrm{~K}_{\mathrm{L}}(\mathrm{L} / \mu \mathrm{g})$ & $\mathrm{q}_{\mathrm{m} \text { calc }}(\mu \mathrm{g} / \mathrm{g})$ & $\mathrm{R}^{2}$ \\
\hline 1.008 & 0.5641 & 0.9067 & 0.022 & 21.8 & 0.9938 \\
\hline
\end{tabular}

Thus the isotherm follows the sorption process in the entire concentration range studied. Furthermore, the maximum $\mathrm{As}(\mathrm{V})$ uptake obtained from the Langmuir plot is almost the same with the maximum $\operatorname{As}(\mathrm{V})$ uptake experimentally obtained.

The dimensional constant, called separation factor $\left(R_{L}\right)$, was used to describe the essential characteristics of Langmuir isotherm $\left(\mathrm{R}_{\mathrm{L}}>1\right.$, unfavorable; $\mathrm{R}_{\mathrm{L}}=1$, linear; $0<\mathrm{R}_{\mathrm{L}}<1$, favorable; and $\mathrm{R}_{\mathrm{L}}=0$, irreversible),

$$
\mathrm{R}_{\mathrm{L}}=\frac{1}{1+\mathrm{K}_{\mathrm{L}} \cdot \mathrm{C}_{0}}
$$

In fact, the separation factor is a measure of the adsorbent capacity used. $R_{L}$ values were calculated for the entire concentration range studied and found to be greater than 0 and less than 1 , showing favorable adsorption.

\section{Conclusions}

In the present paper the performance of the Fe-IR-120(Na)-DEHPA resin, in the removal process of $\mathrm{As}(\mathrm{V})$ from aqueous solution, has been investigated. The studied materials has been obtained trough impregnation of Amberlite IR-120(Na) resin with DEHPA and because of the high affinity of arsenic towards iron the $\mathrm{Fe}(\mathrm{III})$ ions were loaded onto the functionalized resin. Trough impregnation of the studied resin with DEHPA is obtained a resin with two functional groups. With the increasing of the DEHPA concentration in the impregnation process of the resin increased the quantity of the adsorbed acid by the resin. This led to a higher quantity of iron loaded, which changed the surface morphology of the resin and developed a higher removal capacity of $\operatorname{As}(\mathrm{V})$ from aqueous solution. The FTIR and the SEM and EDX analysis of the materials proved the adsorption of DEHPA and the loading of $\mathrm{Fe}(\mathrm{III})$ ions on the IR-120(Na) support. The optimum condition for the Fe-IR-120(Na)-DEHPA obtaining is the initial concentration of DEHPA used in the impregnation process of $0.08 \mathrm{~g} / \mathrm{mL}$ of solvent and an initial concentration of $\mathrm{Fe}(\mathrm{III})$ ions of $100 \mathrm{mg} / \mathrm{L}$. This materials showed good performance in the removal process of $\mathrm{As}(\mathrm{V})$ from aqueous solutions. By applying the kinetic model to the experimental data it was found that the removal of $\mathrm{As}(\mathrm{V})$ ions by Fe-IR-120(Na)-DEHPA follows the pseudo-second-order rate kinetics. The linear Langmuir and Freundlich isotherm models were used to represent the experimental data and these could be relatively well interpreted by the Langmuir isotherm. 
$R_{L}$ values between 0 and 1.0 further indicate $a$ favorable adsorption of $\mathrm{As}(\mathrm{V})$ ions onto Fe-IR-120(Na)-DEHPA. The maximum As(V) ions uptake calculated from Langmuir model was $21.8 \mu \mathrm{g} / \mathrm{g}$.

\section{Acknowledgment}

This work was supported by CNCSIS-UEFISCDI, project number PN II-IDEI 927/2008, "Integrated Concept about Depollution of Waters with Arsenic Content, through Adsorption on Oxide Materials, followed by Immobilization of the Resulted Waste in Crystalline Matrices".

This work was partially supported by the strategic grant POSDRU/89/1.5/S/57649, Project ID 57649 (PERFORM-ERA), co-financed by the European Social Fund-Investing in People, within the Sectoral Operational Programme Human Resources Development 2007-2013.

\section{References}

[1] M. Streat, K. Hellgardt, N.L.R. Newton, Hydrous ferric oxide as an adsorbent in water treatment: Part 2. Adsorption studies, Process Safety and Environmental Protection 86 (2008) 11-20.

[2] J. Jonsson, D.M. Sherman, Sorption of As(III) and As(V) to siderite, green rust (fougerite) and magnetite, implications for arsenic release in anoxic groundwaters, Chem. Geol. 255 (2008) 173-181.

[3] D. Borah, S. Satokawa, S. Kato, T. Kojima, Sorption of As(V) from aqueous solution using acid modified carbon black, J. Hazard. Mater. 162 (2009) 1269-1277.

[4] P. Chutia, S. Kato, T. Kojima, S. Satokawa, Adsorption of As(V) on surfactant-modified natural zeolites, J. Hazard. Mater. 162 (2009) 204-211.

[5] D. Borah, S. Satokawa, S. Kato, K. Kojima, Surface-modified carbon black for As(V) removal, J. Colloid Interface Sci. 319 (2008) 53-62.

[6] S.K. Maji, A. Pal, T. Pal, Arsenic removal from real-life groundwater by adsorption on laterite soil, J. Hazard. Mater. 151 (2008) 811-820.

[7] K. Gupta, U.C. Ghosh, Arsenic removal using hydrous nanostructure iron(III)-titanium(IV) binary mixed oxide from aqueous solution, J. Hazard. Mater. 161 (2009) 884-892.

[8] K. Banerjee, G.L. Amy, M. Prevost, S. Nour, M. Jekel, P.M. Gallagher, et al., Kinetic and thermodynamic aspects of adsorption of arsenic onto granular ferric hydroxide
(GFH), Water Res. 42 (2008) 3371-3378.

[9] F. Partey, D. Norman, S. Ndur, R. Nartey, Arsenic sorption onto laterite iron concretions: temperature effect, J. Colloid Interface Sci. 321 (2008) 493-500.

[10] J.C. Hsu, C.J. Lin, C.H. Liao, S.T. Chen, Removal of As(V) and $\mathrm{As}(\mathrm{III})$ by reclaimed iron-oxide coated sands, J. Hazard. Mater. 153 (2008) 817-826.

[11] V.T. Nguyen, S. Vigneswaran, H.H. Ngo, H.K. Shon, J. Kandasamy, Arsenic removal by a membrane hybrid filtration system, Desalination 236 (2009) 363-369.

[12] Y.N. Chen, L.Y. Chai, Y.D. Shu, Study of arsenic(V) adsorption on bone char from aqueous solution, J. Hazard. Mater. 160 (2008) 168-172.

[13] S. Song, A. Lopez-Valdivieso, D.J. Hernandez-Campos, C. Peng, M.G. Monroy-Fernandez, I. Razo-Soto, Arsenic removal from high-arsenic water by enhanced coagulation with ferric ions and coarse calcite, Water Res. 40 (2006) 364-372.

[14] M.B. Baskan, A. Pala, Determination of arsenic removal efficiency by ferric ions using response surface methodology, J. Hazard. Mater. 166 (2009) 796-801.

[15] J.R. Parga, D.L. Cocke, J.L. Valenzuela, J.A. Gomes, M. Kesmez, G. Irwin, et al., Arsenic removal via electrocoagulation from heavy metal contaminated groundwater in La Comarca Lagunera Mexico, J. Hazard. Mater. B 124 (2005) 247-254.

[16] D. Qu, J. Wang, D. Hou, Z. Luan, B. Fan, C. Zhao, Experimental study of arsenic removal by direct contact membrane distillation, J. Hazard. Mater. 163 (2009) 874-879.

[17] R.Y. Ning, Arsenic removal by reverse osmosis, Desalination 143 (2002) 237-241.

[18] K. Kosutic, L. Furac, Removal of arsenic and pesticides from drinking water by nanofiltration membranes, Sep. Purif. Technol. 42 (2005) 137-144.

[19] J. Kim, M.M. Benjamin, Modeling a novel ion exchange process for arsenic and nitrate removal, Water Res. 38 (2004) 2053-2062.

[20] N. Balasubramanian, T. Kojima, C.A. Basha, C. Srinivasakannan, Removal of arsenic from aqueous solution using electrocoagulation, J. Hazard. Mater. 167 (2009) 966-969.

[21] M. Chabani, A. Amrane, A. Bensmaili, Kinetics of nitrates adsorption on Amberlite IRA-400 resin, Desalination 206 (2007) 560-567.

[22] S. Mustafa, K.H. Shah, A. Naeem, M. Waseem, M. Tahir, Chromium (III) removal by weak acid exchanger Amberlite IRC-50 (Na), J. Hazard. Mater. 160 (2008) 1-5.

[23] W. Shao, X. Li, Q. Cao, F. Luo, J. Li, Y. Du, Adsorption of arsenate and arsenite anions from aqueous medium by using metal (III)-loaded Amberlite resins, Hydrometallurgy 91 (2008) 138-143. 
[24] X. Zhu, A. Jyo, Removal of $\operatorname{arsenic}(V)$ by zirconium(IV)-loaded phosphoric acid chelating resin, Sep. Sci. Technol. 36 (2001) 3175-3189.

[25] M. Chanda, K.F. O’Driscoll, G.L. Rempel, Ligand exchange sorption of arsenate and arsenite anions by chelatin resins in ferric ion form: II. Iminodiacetic chelatin resin Chelex 100, React. Polym. 8 (1988) 85-95.

[26] B. An., T.R. Steinwinder, D. Zhao, Selective removal of arsenate from drinking water using a polymeric ligand exchanger, Water Res. 39 (2005) 4993-5004.

[27] D. Monah, C.U. Pittman, Arsenic removal from water/wastewater using adsorbents: a critical review, J. Hazard. Mater. 142 (2007) 1-53.

[28] N.E. Belkhouche, M.A. Didi, Extraction of Bi(III) from nitrate medium by D2EHPA impregnated onto Amberlite XAD-1180, Hydrometallurgy 103 (2010) 60-67.

[29] B. Saha, R.J. Gill, D.G. Bailey, N. Kabay, M. Arda, Sorption of $\mathrm{Cr}(\mathrm{VI})$ from aqueous solution by Amberlite XAD-7 resin impregnated with Aliquat 336, React. Funct. Polym. 60 (2004) 223-244.

[30] C.M. Davidescu, M. Ciopec, A. Negrea, L. Lupa, P. Negrea, C. Muntean, et al., Use of di-(2-ethylhexyl)phosphoric acid (DEHPA) impregnated XAD-7 copolymer resin for the separation of chromium (III) from water, Rev. Chim. (Bucureşti) 62 (2011). (in press)

[31] M. Ciopec, A. Negrea, C.M. Davidescu, P. Negrea, A. Popa, C. Muntean, Adsorption of trace metals by XAD7 impregnated resins with di-(2-ethylhexyl)-phosphoric acid (DEHPA), Annals of Vest Univ. Timisoara, Series of Chemistry 19 (4) (2010) 9-18.

[32] M. Ciopec, A. Negrea, C.M. Davidescu, P. Negrea, C.
Muntean, A. Popa, Use of di-(2-Ethylhexyl)-phosphoric acid (DEHPA) impregnated XAD-8 copolymer resin for the separation of metal ions from water, Chem. Bull. "Politehnica" Univ. Timisoara 55 (69) 2 (2010) 127-131.

[33] A. Janin, J.F. Blais, G. Mercier, P. Drogui, Selective recovery of $\mathrm{Cr}$ and $\mathrm{Cu}$ in leachate from chromated copper arsenate treated wood using chelating and acidic ion exchange resins, J. Hazard. Mater. 169 (2009) 1099-1105.

[34] K.S. Rao, M. Mohapatra, S. Anand, P. Venkateswarlu, Review on cadmium removal from aqueous solution, Int. J. Eng. Sci. Technol. 2 (2010) 81-103.

[35] M.K. Jha, N.V. Nguyen, J.C. Lee, J. Jeong, J.M. Yoo, Adsorption of copper from the sulphate solution of low copper contents using the cationic resin Amberlite IR 120, J. Hazard. Mater.164 (2009) 948-953.

[36] S. Kocaoba, G. Akcin, Removal of chromium (III) and cadmium (II) from aqueous solutions, Desalination 180 (2005) 151-156.

[37] M. Benamor, Z. Bouariche, T. Belaid, M.T. Draa, Kinetic studies on cadmium ions by Amberlite XAD7 impregnated resin containing di(2-ethylhexyl) phosphoric acid as extractant, Sep. Purif. Technol. 59 (2008) 74-84.

[38] F.J. Alguacil, M. Alonso, L. Javier, Chromium (III) recovery from waste acid solution by ion exchange processing using Amberlite IR-120 resin: batch and continuous ion exchange modelling, Chemosphere 57 (2004) 789-793.

[39] A. Negrea, L. Lupa, M. Ciopec, R. Lazau, C. Muntean, P. Negrea, Adsorption of As(III) ions onto iron-containing waste sludge, Adsorpt. Sci. Technol. 28 (2010) 467-484. 